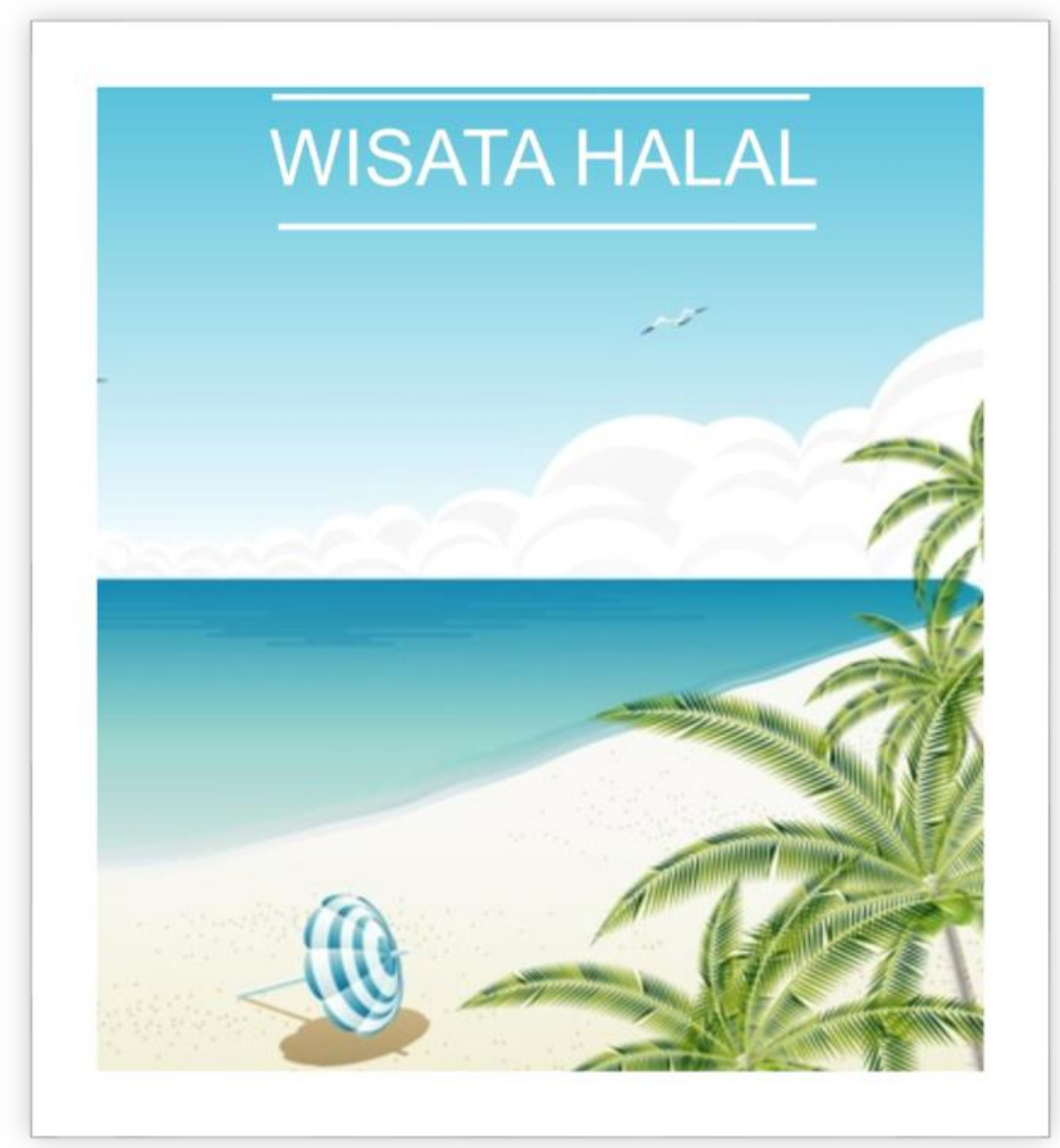

\title{
Critical Review: Risk Assessment of Halal Products and Services YUDI PURNAMA DANI
}




\section{Literature Review}

Title : Risk assessment of halal products and services: Implication for tourism industry

Authors $\quad$ : Hossein G.T. Olya \& Amr Al-ansi

Year $\quad: 2018$

Variable : Health Risk $\left(\mathrm{X}_{1}\right)$, Psychological Risk $\left(\mathrm{X}_{2}\right)$, Environmental Risk $\left(\mathrm{X}_{3}\right)$, Social Risk $\left(\mathrm{X}_{4}\right)$, Quality Risk $\left(\mathrm{X}_{5}\right)$, Financial Risk $\left(\mathrm{X}_{6}\right)$, Time-loss Risk $\left(\mathrm{X}_{7}\right)$, Satisfaction $\left(\mathrm{Y}_{1}\right)$, Intention to Recommend $\left(\mathrm{Y}_{2}\right)$, Continued Intention to Use $\left(\mathrm{Y}_{3}\right)$.

Method : Statistical Analysis with SEM (Structural Equation Modeling)

Results :

Penelitian ini berfokus pada halal dan haram, yang merupakan konsep yang harus diterapkan di semua aspek kehidupan Muslim. Setiap ndividu harus mampu membedakan produk dan layanan halal ataupun haram. Gagal dalam memilih barang halal, konsumen menghadapi berbagai macam risiko, seperti kesehatan, psikologis, lingkungan, sosial, kualitas, keuangan, dan risiko kehilangan waktu. Temuan penelitian ini bisa membantu industri pariwisata dalam memahami cara memperlakukan dan melayani keduanya Muslim dan non-Muslim yang sensitif terhadap barang halal. Industri pariwisata bisa menjadi pelopor dalam integrasi manusia dengan nilai dan kepentingan bisnis dengan menciptakan dan memberikan produk dan layanan halal kepada individu. Dari perspektif turis, barang halal memiliki nilai budaya; Oleh karena itu, mengatasi risiko yang ditimbulkan, bisa dengan cara meningkatkan kepuasan dan kesetiaan wisatawan. 


\section{Introduction}

Pariwisata sudah menjadi sesuatu yang penting dan tidak dapat dipisahkan dalam kehidupan manusia (Evanita, 2014). Kegiatan berwisata seakan menjadi kebutuhan yang harus dipenuhi oleh setiap manusia. Dewasa ini, seiring dengan perkembangan teknologi yang merambah setiap aspek kehidupan manusia tidak terkecuali pariwisata. Teknologi membantu manusia dalam memberikan dan menerima berbagai informasi mengenai pariwisata mulai dari layanan, produk dan fasilitas. Dengan adanya teknologi seperti ini wisatawan dengan mudah dalam memilih destinasi yang diinginkan sesuai dengan keinginan dan kemampuannya masing-masing.

Hadirnya teknologi membentuk berbagai kebutuhan dan keinginan penggunanya (Trinanda, 2014). Kemudahan dari layanan dan akses informasi yang tanpa batas membuat manusia berfikir untuk menyesuaikan kebutuhannya terhadap wisata termasuk wisata halal. Pariwisata halal hadir karena adanya kesadaran wisatawan muslim bahwa penting untuk memilih dan menggunakan wisata yang sesuai dengan aturan hidup umat islam yang diatur dalam Al-Qur'an dan Hadits. Kesadaran ini timbul karena adanya kekawatiran wisatawan muslim yang hendak berkunjung ke suatu destinasi ataupun negara yang agama islamnya minoritas Kekawatiran terbesar bagi wisatawan untuk berwisata ke negara yang minoritas muslim terutama pada produk makanannya, berdasarkan penelitian dari Al-Ansi, Olya, dan Han (2017), menjelaskan bahwa makanan menjadi poin pertama yang menjadi pertimbangan wisatawan muslim berkunjung ke suatu destinasi ataupun negara. Jaminan halal dari makanan menjadi hal yang sangat sensitif bagi kalangan wisatawan muslim selain tempat sholat.

Untuk mendukung berbagai informasi produk dan layanan pariwisata halal Crescentrating.com yang merupakan sebuah situs website yang menyediakan berbagai informasi mengenai pariwisata halal menerbitkan laporan mengenai perikat negara dengan destinasi wisata halal terbaik pada tahun 2018. Daftar 
peringkat ini dibagi menjadi dua, yaitu peringkat untuk negara yang tergabung dalam OIC (Organization of Islamic Coorporation) atau yang bisa disebut OKI (Organisasi Kerjasama Islam) serta negara yang tidak tergabung dalam OKI.

\section{Tabel 1. Peringkat Negara Wisata Halal Dunia Tahun 2018}

\begin{tabular}{|c|c|c|c|c|c|}
\hline \multicolumn{3}{|c|}{ Kategori Destinasi OKI } & \multicolumn{3}{c|}{ Kategori Destinasi Non-OKI } \\
\hline Ranking & Skor & Negara & Ranking & Skor & Negara \\
\hline 1 & 80.6 & Malaysia & 1 & 66.2 & Sigapura \\
\hline 2 & 72.8 & UEA \& Indonesia & 2 & 56.1 & Thailand \\
\hline 3 & 69.1 & Turki & 3 & 53.8 & Inggris \\
\hline 4 & 68.7 & Arab Saudi & 4 & 51.4 & Jepang \\
\hline 5 & 66.2 & Qatar & 5 & 49.6 & Taiwan \& Hongkong \\
\hline 6 & 65.9 & Bahrain & 6 & 47.7 & Afrika Selatan \\
\hline 7 & 65.1 & Oman & 7 & 45.7 & Jerman \\
\hline 8 & 61.7 & Maroko & 8 & 45.2 & Perancis \\
\hline 9 & 60.5 & Kuwait & 9 & 44.7 & Australia \\
\hline
\end{tabular}

Sumber: Crescentrating.com (2018)

Dari data di atas terihat bahwa dalam kategori destinasi OKI Malaysia menduduki posisi teratas untuk sebagai negara pariwisata halal dunia dengan poin perolehan sebesar 8o.6 disusul United Emirat Arab (UEA) dan Indonesia dengan perolehan poin 72.9 dan pada posisi ketiga Turki dengan perolehan poin 69.1. Untuk kategori destinasi non-OKI Singapura memegang skor tertinggi dengan perolehan skor 66.2 disusul oleh Thailand dan Inggris, sementara Taiwan dan Jepang terus meningkatkan posisi mereka untuk kategori wisata halal dunia.

Malaysia bukan merupakan negara mayoritas muslim terbesar di dunia secara mengejutkan berturut-turut selama depan tahun kembali menjuarai indeks wisata halal dunia. Sedangkan Indoneisa berhasil naik di urutan kedua bersama Uni Emirat Arab․ Sebagai negara muslim terbesar didunia Indonesia² cukup puas bertahan pada posisi kedua, dengan keanekaragaman destinasi wisata,

\footnotetext{
${ }^{1}$ Kompas.com

${ }^{2}$ Pew Research Centre
} 
peningkatan pelayanan, dan promosi diharapkan tahun depan dan tahun-tahun berikutnya Indonesia dapat menduduki pada posisi pertama.

\section{Results and Discussion}

Berdasarkan penjabaran pada latar belakang menjelaskan pentingnya pariwisata halal dikarenakan besarnya pangsa pasar pariwisata halal dan tentunya akan memberikan peluang yang besar bagi negara terutama dari sisi ekonomi. Beranjak dari fenomena tersebut yang menjadi pernyataan adalah "Kenapa bukan Indonesia yang menduduki posisi pertama?." Pertanyaan tersebut tentunya perlu analisis yang mendalam terhadap faktor-faktor yang menyebabkan sehingga Indonesia cukup puas pada posisi kedua.

Pada tulisan ini saya jabarkan beberapa analisa saya mengenai Pariwisata Malaysia berdasarkan dari penelitian yang berjudul Risk assessment of halal products and services: Implication for tourism industry karangan Hossein G.T. Olya \& Amr Al-ansi yang diterbitkan pada tahun 2018. Sedikit berbicara mengenai tulisan ini, penting bagi wisatawan yang berkunjung ke Malaysia untuk memperhatikan setiap aspek halal layanan maupun produk wisata yang ditawarkan sehingga berbagai resiko seperti resiko kesehatan, psikologis, lingkungan, sosial, kualitas, keuangan, dan kehilangan waktu dapat dihindari. Penelitian ini menggunakan metode Statistical Analysis dengan SEM (Structural Equation Modeling) dengan cara menyebarkan seperangkat daftar pertanyaan ataupun pernyataan kepada 320 orang responden. Hasil penelitian ini diperoleh dari tabulasi data jawaban responden yang dianalisis dengan 8 (delapan) langkah yang dapat kita lihat pada gambar 1 dibawah ini. 


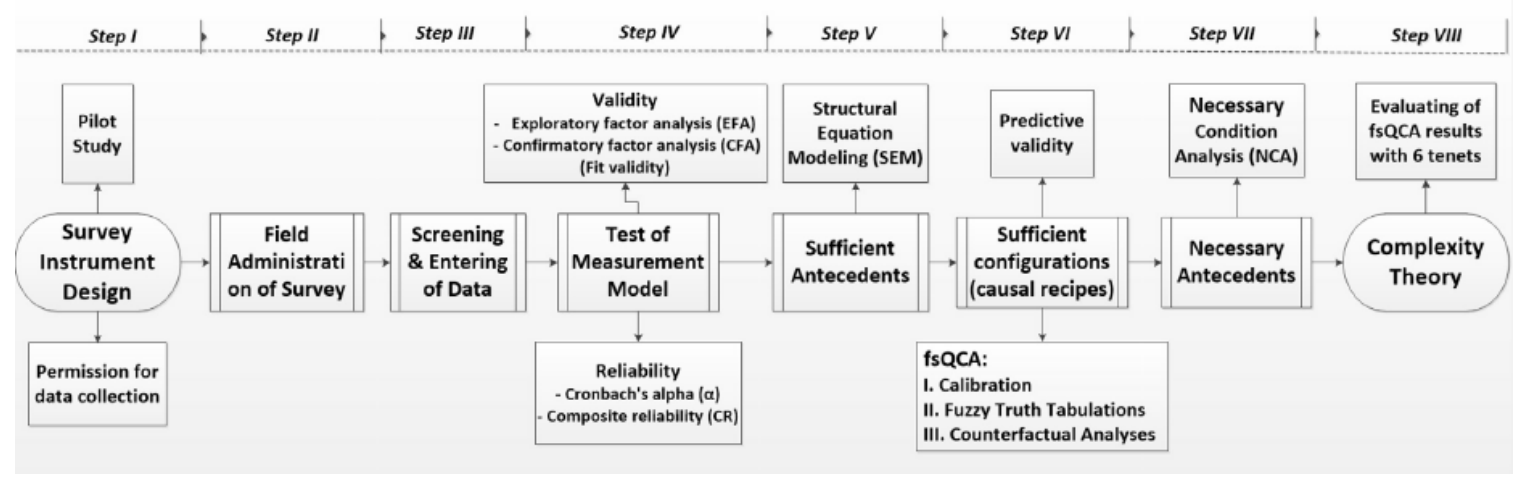

Gambar 1. Langkah-langkah Penelitian

Sumber: Olya \& Al Ansi (2018:282)

Dari hasil penelitian menjunjukkan bahwa Malaysia sangat memperhatikan setiap aspek-aspek penting dalam pariwisata halal sehingga tidak sulit untuk Malaysia untuk tetap bertahan pada posisi pertama sebagai negara wisata halal dunia. Sebagai negara yang dengan populasi $60,5 \%$ beragama islam ${ }^{3}$, sehingga tidak sulit bagi Malaysia untuk mempromosikan dan mengait wisatawan muslim. tidak hanya itu, berbagai fasilitas-fasilitas ibadah tersedia hamper diseluruh Malaysia sehingga tidak membutuhkan biaya yang besar dalam membangun fasilitas-fasilitas ibadah sebagai idikator penting dalam wisata halal. Hasil penelitian tersebut menunjukkan ada 7 pokok utama yang terus dikembangkan dan menjadi andalan bagi Malaysia untuk menjadi negara yang menerapkan wisata halal. Pokok-pokok tersebut adalah resiko kesehatan, psikologis, lingkungan, sosial, kualitas, keuangan, dan kehilangan waktu dapat dihindari. Resiko-resiko tersebut sangat dipertimbangkan oleh Malaysia sehingga dengan memperhatikan resiko tersebut Malaysia mampu menjadi negara pertama yang benar-benar menerapkan pariwisata halal didunia.

\footnotetext{
3 Wikipedia.org
} 
Preferences:

Evanita, S., \& Trinanda, O. (2017). MINANGKABAU TRADITIONAL FOOD VS MODERN SNACKS: THE INFLUENCE OF PRODUCT ATTRIBUTES ON TEENAGERS BUYING INTEREST IN WEST SUMATERA'S URBAN CITIES.

Olya, Hossein G.T \& Amr Al-ansi, Amr.2018. "Risk assessment of halal products and services: Implication for tourism industry." Journal Tourism Management, 279-291.

Trinanda, O. (2014). FIGHTING BRAND \& MAIN BRAND: ANALISIS PERSEPSI KONSUMEN TERHADAP BAURAN PEMASARAN LINI PRODUK PT. SOSRO. Jurnal Kajian Manajemen Bisnis, 3(o2).

Trinanda, O. (2015). The Re-branding of IKIP Padang to UNP: How the Changes in Brand Awareness and Brand Image Would Affect Student's Enrollment Interest?.

https://www.crescentrating.com/

https://ms.wikipedia.org

http://www.pewresearch.org/ 